\title{
Chemical Characterization of Artemisia Annua L. Extract Assessment of Antioxidant Activity in vitro and in vivo Toxicity Studies
}

\author{
ROXANA LIANA STAN ${ }^{1}$, BOGDAN SEVASTRE², ADRIANA CORINA HANGAN ${ }^{3 *}$, SANDA BOTA ${ }^{4}$, DANIELA HANGANU ${ }^{5}$, \\ CORINA MARIA LUCIA IONESCU ${ }^{1}$, CRISTIAN POPOVICI ${ }^{2}$, ALEXANDRA CRISTINA SEVASTRE-BERGHIAN ${ }^{6}$, \\ ALEXANDRA DREANCA², LAURA GRATIELA VICAS ${ }^{7}$
}

'University of Medicine and Pharmacy luliu-Hatieganu, Faculty of Pharmacy, Department of Pharmaceutical Biochemistry and Clinical Laboratory, 8 Victor Babes Str., 400012, Cluj-Napoca, Romania

2University of Agricultural Science and Veterinary Medicine, 3-5 Calea Manastur, 400372, Cluj-Napoca, Romania

3University of Medicine and Pharmacy luliu-Hatieganu, Faculty of Pharmacy, Department of Inorganic Chemistry, 8 Victor Babes Str., 400012, Cluj-Napoca, Romania

${ }^{4}$ University of Oradea, Faculty of Sciences, Department of Chemistry, 1 Universitatii Str., 419987, Oradea, Romania

5 University of Medicine and Pharmacy luliu-Hatieganu Cluj-Napoca, Faculty of Pharmacy, Department of Pharmacognosy, 8 Victor Babes Str., 400012, Cluj-Napoca, Romania

${ }^{6}$ University of Medicine and Pharmacy luliu-Hatieganu, Faculty of Medicine, Department of Physiology, 8 Victor Babes Str., 400012, Cluj-Napoca, Romania

${ }^{7}$ University of Oradea, Faculty of Medicine and Pharmacy, Department of Pharmacy, 1 Universitatii Str.,419987, Oradea, Romania

The purpose of the study was to demonstrate in vitro antioxidant activity and in vivo toxicity of the Artemisia Annua L. extract. The plant was harvested from Bihor area (Cri'ul Repede and Negru river valleys), Romania. Preparation of the plant product and of the lyophilizated extract was carried out in accordance with the Romanian Pharmacopeia $X^{\text {th }}$ Edition. Lyophilized extract was evaluated in terms of polyphenol content using HPLC method. Antioxidant activity was highlighted using the DPPH, ABTS and FRAP methods. Hepatic, renal and haematological toxicity studies have been performed on laboratory mice. For this purpose blood and organs were collected. Biochemical and haematological parameters were determined on the blood samples and histopathological examination was performed on organs. In vitro antioxidant effect of Artemisia Annua L extract and its lack of in vivo toxicity were demonstrated. It is desirable to obtain a new phytoproduct harvested from spontaneous flora of Romania with antioxidant/antitumoral properties and which is devoid of toxicity.

Keywords: extract, antioxidant, toxicity, phytoproduct

There has been an increase in the reevaluation of traditional medicinal plants worldwide, with extensive research on various plant species and their therapeutic properties being carried out. Traditional medicinal plant remedies have been highlighted as alternative medicines that are less likely to cause adverse side effects, unlike synthetically generated by chemical substances [1-6].

Artemisia annua $L$, which is also known as sweet wormwood and Qinghao, Asteracea family, is an annual herb, native to temperate Asia but naturalized throughout the world. It has fern-like leaves, bright yellow flowers and a camphor-like scent [7].

Artemisia annua $L$ has been used for at least 1600 years in traditional Chinese herbal medicine to treat symptoms associated with malaria. Herba Artemisia annua was cited in the Classified Materia Medica as a food supplement related to longevity, a characteristic probably associated with its antiparasitic and antioxidant properties [8,9]. Has been used also, for many centuries in traditional Asian medicine for the treatment and prevention of fever and chills [1]. In previous studies, Artemisia species has been reported to exhibit anticancer, antioxidant, antidiabetic, antihepatitis, antihypertensive, antibacterial, antifungal, anti-inflammatory and antiviral effects [10-13].

A variety of compounds have been extracted from Artemisia annua $L$ such as sesquiterpenoids, flavonoids, coumarins, lipids, phenolics, purines, steroids, triterpenoids, aliphatics and artemisinin [14,15].
Free radicals in the form or reactive oxygen and nitrogen species are an integral part of normal physiology, and free radical reactions occur throughout the human body. Overproduction of these reactive species can occur due to oxidative stress caused by imbalances in the body's antioxidant defence system and free radical formation. These reactive species can interact with biomolecules, causing injury and death. So, reactive oxygen species (ROS) such as the superoxide anion, hydroxyl radical and hydrogen peroxide are known as inducers of arteriosclerosis, cancer, diabetes and aging [16-18].

Antioxidants can remove ROS, therefore, many methods for evaluating their activity have been reported [19-22]. Among these methods, the 2,2-diphenyl-1-picryl-hydrazyl (DPPH) and 2,2'-azino-bis(3-ethylbenzothiazoline-6sulfonic acid) (ABTS) assays have been widely used [2325].

Phenolic compounds exert multiple biological effects, including antioxidant and free radical-scavenging abilities. Their anti-radical property is directed toward hydroxyl radical and superoxide anion, highly reactive species, especially the last one being one of the main ROS involved in the DNA damage processes [26-29].

The first objective of this study was to demonstrate in vitro antioxidant activity of Artemisia annua $L$ herba harvasted from Bihor area, Romania. The second objective of the study was to demonstrate the lack of toxicity of Artemisia annua $L$ extract. In the future, it is desirable to obtain a new active phytoproduct without toxicity.

\footnotetext{
*email: acomsa6@yahoo.com
} 


\section{Experimental part}

Materials and methods

Plant matrial and extraction

Artemisia annua L. (Asteraceae) was harvested from Bihor area (Cri'ul Repede and Negru river valleys), Romania. The plant harvest was performed according to the Good Agricultural and Collection Practices rules, from an unpolluted area. The vegetal product (herba) was dried at $40^{\circ} \mathrm{C}$ in an oven for total moisture removal and then was crushed according to the Romanian Pharmacopoeias $10^{\text {th }}$ edition (passing through the sieve number I) [30].

Artemisia annua $L$. extract was prepared by maceration with alcohol, accordingly to the Romanian Pharmacopoeias $10^{\text {th }}$ edition (the ratio vegetal product/ alcohol $\left.30^{\circ}=20 \%\right)$, at room temperature $\left(20^{\circ} \mathrm{C}\right)$, for $24 \mathrm{~h}$, with periodic mixing, pressed and filtered [30]. The hydroalcoholic extracts were centrifuged and supernatants were evaporated to dryness under vacuum in a rotavapor. The dry extract was dispersed in $10 \mathrm{~mL}$ distilled water and frozen at $-25^{\circ} \mathrm{C}$. Finally, they were brought into the lyophilizer using Freeze dryer Alpha 1-2 Christ (Martin Christ, Osterode am Harz, Germany). The lyophilized extracts were weighed and transferred to a dry sealed container. A brown powder with homogeneous, spongy appearance was obtained.

Identification and quantification of polyphenols in Artemisia Annua L. extract

Identification of polyphenols from Artemisia Annua $L$ extract was performed using a system ACME $9000 \mathrm{HPLC}$ equipped with an UV detector. It was used a column Phenomenex 00F-4439-Y0, gemini c18 150 x 3, 110A. The elution was an isocratic one, using a mobile phase with the following composition - water: methanol: acetic acid $(700: 300: 2)(\mathrm{v} / \mathrm{v})$. The following parameters were used: liquid flow $0.4 \mathrm{~mL} / \mathrm{min}$, injection volume $20 \mu \mathrm{L}$, column temperature $25^{\circ} \mathrm{C}$. The detection was performed at 300 and $360 \mathrm{~nm}$ wavelengths. The polyphenols were identified by comparing the retention time of the compounds from the extract with that of the standard quercetin solution.

The standard quercetin solution was prepared by dissolving $0.01 \mathrm{~g}$ quercetin in a mixture of methanol:water (50:50) and then brought into a $5 \mathrm{~mL}$ rated balloon (concentration of the solution: $2 \mathrm{mg} / \mathrm{mL}$ ).

$1.6201 \mathrm{~g}$ of Artemisia Annua L extract was dissolved in a mixture of methanol:water (50:50) and brought into a $10 \mathrm{~mL}$ rated balloon. The solution showed a slight opalescence and for this reason it was filtered and diluted 1:10 with the same solvent mixture.

The standard and the extract solutions were analyzed three times to determine the retention times and the peak area.

The determination of in vitro antioxidant capacity of the lyophilized extract

Measurement of DPPH radical scavenging activity

DPPH (2,2-diphenyl-1-picryl-hydrazyl-hydrate) radical scavenging activity was assessed according to Kikuzaki et al [31]. In this assay, $50 \mu \mathrm{L}$ extract of fraction solutions with different concentrations were added with $1.0 \mathrm{~mL}$ of $0.4 \mathrm{mM}$ methanolic - DPPH and brought up with methanol to $5.0 \mathrm{~mL}$. The mixture was shaken vigorously using a vortex and left to stand for $15 \mathrm{~min}$, at room temperature, in dark. The scavenging effect on the DPPH radical was read using spectrophotometer (Genesys-10) at $517 \mathrm{~nm}$. The radical scavenging activity was expressed as radical scavenging percentage using the following equation: $\%$ Inhibition = $\left[\left(A_{B}-A_{A}\right) / A_{B}\right] \times 100$; where, $A_{B}=$ absorption of blank sample ( $\mathrm{t}=0 \mathrm{~min}.), \mathrm{A}_{\mathrm{A}}=$ absorption of test extract solution $(t=15 \mathrm{~min}$.). The DPPH solution without sample solution was used as control.

\section{ABTS method}

ABTS method (2,2'-Azinobis [3-ethylbenzothiazoline-6sulfonic acid]-diammonium salt) named also TEAC method (Trolox Equivalents Antioxidant Capacity) is a spectrophotometric method which measures the ability of compounds to scavenge the $\mathrm{ABTS}^{+}$cation radical in relation to Trolox. Shortly, the ABTS ${ }^{+}$cation radical was produced by reacting the $A B T S^{+}$solution $(7 \mathrm{mM})$ with potassium persulfate $(2,45 \mathrm{mM})$ solution, keeping the mixture in dark at room temperature for $16 \mathrm{~h}$. ABTS stock solution was diluted in order to obtain an absorbance of $0.7 \pm 0.02$ at $734 \mathrm{~nm}$. After addition of $25 \mu \mathrm{L}$ extract to 2.5 $\mathrm{mL}$ of diluted $\mathrm{ABTS}^{+}$, the solution was mixed very well (using vortex) for 30 seconds and the interaction between the antioxidants and the ABTS ${ }^{+}$was monitored spectrophotometricaly at $734 \mathrm{~nm}$, exactly at 1 minute. The calibration curve was linear for the range of Trolox concentrations between 0.125 and $2 \mathrm{mmol} / \mathrm{L}$. The ABTS value was obtained using the following equation based on the calibration curve: $y=1629 x+98.94\left(R^{2}=0.998\right)$, where $\mathrm{x}=$ absorbance and $\mathrm{y}=\mu \mathrm{mol}$ Trolox equivalent $[32,33]$.

\section{FRAP method}

FRAP method (Ferric Reducing Antioxidant Power) is a simple spectrophotometric method that assesses the antioxidant power of the studied samples, being based on the reduction of ferric tripyridyltriazine complex [Fe(III)TPTZ] by a reductant, at an acid $\mathrm{pH}$. The stock solutions included: $300 \mathrm{mM}$ acetate buffer; $270 \mathrm{mg} \mathrm{FeCl} \cdot 6 \mathrm{H}_{2} \mathrm{O}$ dissolved in $50 \mathrm{~mL}$ distillated water; $150 \mathrm{mg} \mathrm{TPTZ}$ and 150 $\mu \mathrm{L} \mathrm{HCl}$, dissolved in $50 \mathrm{~mL}$ distillated water. The working FRAP solution was freshly prepared by mixing $50 \mathrm{~mL}$ acetate buffer, $5 \mathrm{~mL} \mathrm{FeCl} \cdot 6 \mathrm{H}_{2} \mathrm{O}$ solution and $5 \mathrm{~mL}$ TPTZ solution. Trolox was used as a standard solution, the calibration curve was made for concentrations between 0 and 300 $\mu \mathrm{M}$, having a correlation coefficient $R^{2}=0.9956$ and the regression equation $(y=0.0017 x+0.0848)$, where $x=$ absorbance registered at $595 \mathrm{~nm}$ and $\mathrm{y}=\mu \mathrm{mol}$ Trolox equivalent [34-36].

The reagents used for the evaluation of "in vitro" antioxidant activity were purchased from Sigma-Aldrich (St. Louis, MO, USA).

In vivo toxicity study of the Artemisia Annua L. extract Animal care and experimental procedures

A subacute toxicity testwas performed on 10 adult Swiss mice, $34.5 \pm 2.5 \mathrm{~g}$ body weight, 5 male and 5 females. The mice were supplied by luliu Hatieganu University of Medicine and Pharmacy, Cluj-Napoca, Romania. Mice were housed in standard polypropylene cages, at optimum density and in standard laboratory conditions (temperature $25 \pm 1{ }^{\circ} \mathrm{C}$, relative humidity $55 \pm 5 \%$, and $12 \mathrm{~h}$ light/dark cycle). The mice had free access to standard granular diet and water. All the procedures performed on laboratory animals, completed with the European Directive 2010/63/ EU, and the national low 43/2014 for Protection of Animals Used for Scientific Purposes. This project was legally approved by the Comity for Bioethics of UMF (accord no.369/28.IX.2017) and the Veterinary Sanitary Direction and Food Safety (aut. no. 90/10.X.2017). All animals received daily Artemisia annua $L$ extract in a dose of 1000 $\mathrm{mg}$ d.s./ kg b.w., for 14 days long. The body weight and general clinical status was recorded every day. At the end 1904 
the blood was drown from the orbitary sinus under deep narcosis, then the animals were euthanized by narcotic overdose. We performed gross examination immediately after, and fragments of kidney and liver were removed, fixed in buffered formalin and embedded in paraffin wax. Later, the hematoxiline eosine stain was done for histopathology. The blood was used to perform the biochemical and haematological examinations [37].

Biochemical determinations

Liver toxicity study (transaminases, albumin, total protein determinations) and renal toxicity study (creatinine, urea determinations) were performed using a screen point semiautomatic analyzer, STAT - FAX 1904 Plus, Global Medical Instrumentation, Inc. 6511 Bunker Lake Blvd. Ramsey Minnesota, 55303 USA and special determination kits.

\section{Hematological determinations}

Hematologic toxicity testing (erythrogram, leukogram, thrombogram) was performed using an Abacus J unior Vet, Diatron, 3 Diff Messtechnik, Budapest, Hungary. In this purpose, we determined the following haematological parameters: red blood cells (RBC), haemoglobin (HGB), hematocrit(HCT), mean corpuscular volume (MCV), mean corpuscular haemoglobin ( $\mathrm{MCH})$, mean corpuscular haemoglobin concentration (MCHC), red blood cells distribution width (RDW); white blood cells (WBC), lymphocytes (LYM), middle cells (MID), granulocytes (GRA); total platelet count(PLT), platelethematocrit(PCT), mean plateletvolume (MPV) and platelet distribution width (PDWs).

Histopathological analysis

Histopathological analyses of hepatic and renal tissues were performed using an Optical Microscope Olympus I CX41.

\section{Statistical analysis}

All data are reported as the mean \pm Standard Deviation (S.D.). Statistical values were obtained using GraphPad Prism version 5.0 for Windows, GraphPad Software, San Diego California USA.

\section{Results and discussions}

Identification and quantification of polyphenols in Artemisia Annua L. extract

We evaluated the content of polyphenols for the extract of Artemisia Annua $L$ and we expressed them in quercetin. HPLC method was used for the identification and quantification of quercetin. The results obtained by the HPLC method are shown in table 1 and figures 1 and 2 .

The determination of in vitro antioxidant capacity of the lyophilized extract

In vitro antioxidant properties of Artemisia Annua $L$. were determined by three methods, DPPH, ABTS and FRAP. The results are shown in table 2 . Scavenging effect of the plant extract, determined by DPPH method, was measured as percentage of inhibition (\%) of DPPH radical, and the antioxidant capacity of extracts from ABTS and FRAP methods was measured as Trolox equivalents (TE).

\begin{tabular}{|c|c|c|c|c|}
\hline Compound & $\begin{array}{c}\text { Area } \\
(\mathrm{mAU})\end{array}$ & $\begin{array}{c}\text { Retention time } \\
(\mathrm{min})\end{array}$ & $\begin{array}{c}\text { Wavelength } \\
(\mathrm{nm})\end{array}$ & $\begin{array}{c}\text { Assay } \\
(\mathrm{mg} / 100 \mathrm{~g} \text { extract })\end{array}$ \\
\hline Quercetin & 519.6537 & 2.0167 & 360 & 4.1 \\
\hline
\end{tabular}

Table 1

IDENTIFICATION AND QUANTIFICATION OF QUERCETIN IN Artemisia Annua L EXTRACT USING HPLC METHOD

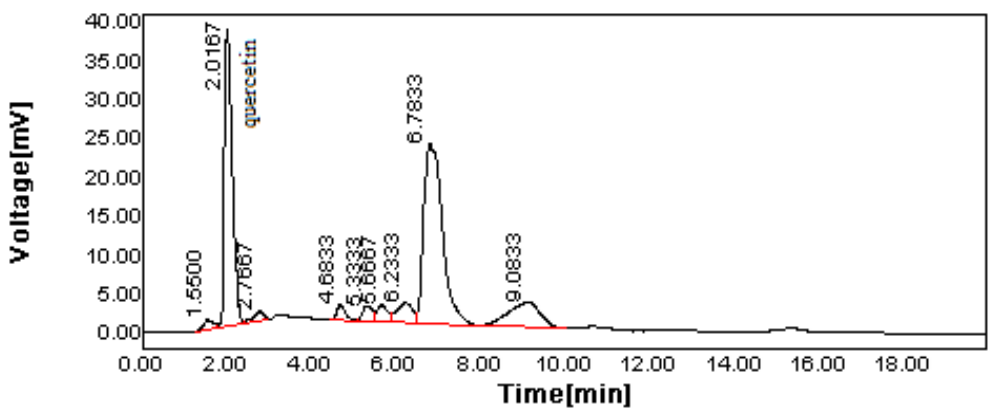

\begin{tabular}{|c|c|c|c|}
\hline Extract & $\begin{array}{c}\text { DPPH } \\
(\%)\end{array}$ & $\begin{array}{c}\text { ABTS } \\
(\mu \mathrm{mol} \mathrm{TE} / \mathrm{g})\end{array}$ & $\begin{array}{c}\text { FRAP } \\
(\mu \mathrm{mol} \mathrm{TE} / \mathrm{g})\end{array}$ \\
\hline Artemisia annua L. & $9.03 \pm 1.11$ & $109.26 \pm 5.98$ & $98.35 \pm 0.00$ \\
\hline
\end{tabular}

Table 2

THE ANTIOXIDANT CAPACITY OF Artemisia Annua L. EXTRACT

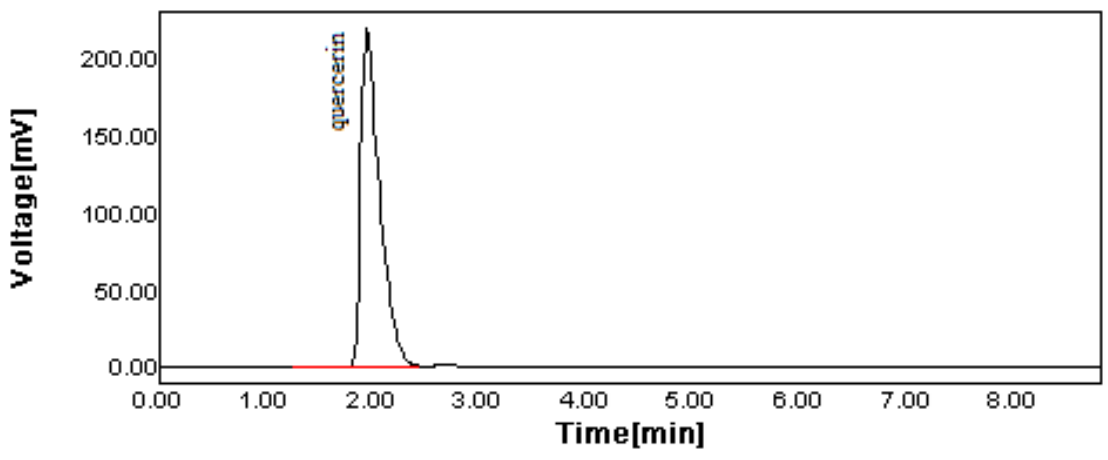

Fig.2. HPLC chromatogram of standard quercetin solution 
Table 3

THE INFLUENCE OF Artemisia Annua L EXTRACT ON BIOCHEMICAL PARAMETERS

\begin{tabular}{|l|l|c|c|c|c|c|}
\hline $\begin{array}{c}\text { Mice } \\
\text { group }\end{array}$ & $\begin{array}{c}\text { Urea } \\
(\mathrm{mg} / \mathrm{dL})\end{array}$ & $\begin{array}{c}\text { Creatinine } \\
(\mathrm{mg} / \mathrm{dL})\end{array}$ & $\begin{array}{c}\text { ALAT } \\
(\mathrm{U} / \mathrm{L})\end{array}$ & $\begin{array}{c}\text { ASAT } \\
(\mathrm{U} / \mathrm{L})\end{array}$ & $\begin{array}{c}\text { Total } \\
\text { protein }(\mathrm{g} / \mathrm{dL})\end{array}$ & $\begin{array}{c}\text { Albumin } \\
(\mathrm{g} / \mathrm{dL})\end{array}$ \\
\hline Male & $15.97 \pm 2.35$ & $0.350 \pm 0.130$ & $32.56 \pm 1.34$ & $125.78 \pm 45.98$ & $5.54 \pm 0.22$ & $3.45 \pm 0.32$ \\
\hline Female & $19.90 \pm 6.52$ & $0.360 \pm 0.182$ & $46.89 \pm 2.54$ & $185.76 \pm 56.72$ & $6.06 \pm 0.18$ \\
\hline
\end{tabular}

Normal values: Urea $12-28 \mathrm{mg} / \mathrm{dL}$, Creatinine 0.3-1 mg/dL, ALAT 26-77U/L, ASAT 54-269 U/L, Total protein 3.5-7.2g/dL, Albumin $2.5-4.8 \mathrm{~g} / \mathrm{dL}$ (Mean $=$ S.E.M.) $(\mathrm{n}=5)[38]$
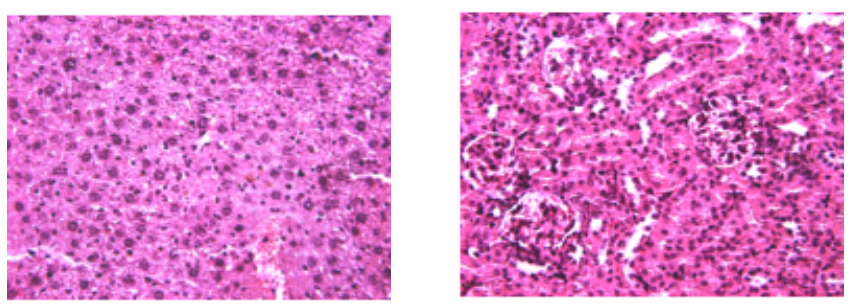

Fig. 3. Histopathological analyses of hepatic and renal tissues.

Table 4

THE INFLUENCE OF Artemisia Annua L EXTRACT ON ERYTHROGRAM

\begin{tabular}{|c|c|c|c|c|c|c|c|}
\hline $\begin{array}{l}\text { Mice } \\
\text { group }\end{array}$ & $\begin{array}{c}\text { RBC } \\
\left(10^{12} / \mathrm{L}\right)\end{array}$ & HGB $(g / d L)$ & $\begin{array}{c}\mathrm{HCT} \\
(\%)\end{array}$ & $\begin{array}{c}M C V \\
\text { (fl) }\end{array}$ & $\begin{array}{c}\mathrm{MCH} \\
(\mathrm{pg})\end{array}$ & $\operatorname{MCHC}(\mathrm{g} / \mathrm{dL})$ & $\begin{array}{c}\text { RDWs } \\
\text { (fl) }\end{array}$ \\
\hline Male & $8.58 \pm 0.81$ & $13.08 \pm 1.31$ & $41.08 \pm 3.01$ & $47.87 \pm 1.34$ & $15.24 \pm 0.19$ & $31.84 \pm 0.68$ & $33.59=1.24$ \\
\hline Female & $8.89 \pm 1.19$ & $14.12 \pm 1.59$ & $44.36 \pm 3.96$ & $49.89 \pm 3.62$ & $15.88 \pm 0.88$ & $31.83 \pm 0.73$ & $35.36 \pm 1.58$ \\
\hline
\end{tabular}

Normal values: RBC 7-12.5 10 $12 / \mathrm{L}$, HGB 10.2-16.6 g/dL, HCT 39-49\% (Mean \pm S.E.M.) (n=5) [38]

\begin{tabular}{|l|l|l|l|l|}
\hline $\begin{array}{c}\text { Mice } \\
\text { group }\end{array}$ & $\begin{array}{c}\text { WBC } \\
\left(10^{9} / \mathrm{L}\right)\end{array}$ & $\begin{array}{c}\text { LYM } \\
\left(10^{9} / \mathrm{L}\right)\end{array}$ & $\begin{array}{c}\text { MID } \\
\left(10^{9} / \mathrm{L}\right)\end{array}$ & $\begin{array}{c}\text { GRA } \\
\left(10^{9} / \mathrm{L}\right)\end{array}$ \\
\hline Male & $9.02 \pm 1.93$ & $6.49 \pm 1.14$ & $0.23 \pm 0.04$ & $2.30 \pm 0.91$ \\
\hline Female & $9.65 \pm 1.77$ & $6.80 \pm 0.46$ & $0.29 \pm 0.09$ & $2.56 \pm 1.21$ \\
\hline
\end{tabular}

Normal value: WBC 6-15 10\%/L (Mean+S.E.M) (n=5) [38]

\begin{tabular}{|l|l|l|l|l|}
\hline $\begin{array}{l}\text { Mice } \\
\text { group }\end{array}$ & $\begin{array}{l}\text { PLT } \\
\left(10^{6} / \mathrm{L}\right)\end{array}$ & $\begin{array}{l}\text { PCT } \\
(\%)\end{array}$ & $\begin{array}{l}\text { MPV } \\
(\mathrm{fl})\end{array}$ & $\begin{array}{l}\text { PDWs } \\
(\mathrm{fl})\end{array}$ \\
\hline Male & $905.60 \pm 149.11$ & $0.59 \pm 0.09$ & $6.56 \pm 0.23$ & $7.04 \pm 0.23$ \\
\hline
\end{tabular}

Table 5
THE INFLUENCE OF Artemisia Annua L EXTRACT ON LEUKOGRAM

The results presented in table 2 demonstrate the in vitro antioxidant activity of the Artemisia Annua L. Iyophilized extract.

In vivo toxicity study of the Artemisia Annua L. extract

Table 3 shows that biochemistry parameters fall within normal limits [38].

The histological study of the liver showed a normal structure, the hepatocytes look normal, are separated by sinus capillaries, bile ducts and supportive tissue. Remack's cellular cords are well-acclaimed, intralobular support tissue is represented by connective tissue, collagen fibers and reticulin in a reduced amount (fig. 3).

The histological study of the kidney revealed a normal aspect of renal parenchyma, in the kidney cortex the renal glomerulus is well defined. Counted tubes present intact cells with spherical core located centrally. The conjunctivovascular tissue in the cortical stroma is poorly represented (fig. 3).

So, biochemistry determinations reflected normal kidney and liver function, aspect confirmed by histopathology studies.

Tables 4-6 show also that haematological parameters fall within normal limits [38].

There were no significant changes in body mass, all the groups in the study having a slight upward trend.

The biochemical and haematological parameters did not change, keeping them within normal limits in all the animals under study. Animals did not show clinical changes during the experiment, all animals survived to the end.

These findings suggest that the Artemisia Annua L. extract is safe.

\section{Conclusions}

In the present study we highlighted in vitro antioxidant activity of Artemisia Annua L extract and we demonstrated the lack of toxicity for Artemisia annua L extract in vivo. In our point of view, these findings justify further studies. So, we purpose to prove in vivo antioxidant activity and to demonstrate de antitumor efficacy of Artemisia Annua $L$ extract in vitro and in vivo. This extract of Artemisia Anuua $L$ might be the basis of a new pharmaceutical remedy using a plant harvested from the spontaneous flora of Romania.

Acknowledgement: Roxana Liana Stan is thankful for the financial support offered by the research grant PN-III-P2-2.1-Cl-2017-0242/2017, concluded between SC Rodia SRL and the University of Medicine and Pharmacy Iuliu-Haieganu Cluj-Napoca, Romania.

\section{References}

1. KIM, W.S., CHOI, W.J ., LEE, S., KIM, W.J., LEE, D.C., SOHN, U.D., SHIN, H.S., KIM, W., Korean J Physiol Pharmacol, 19, 2015, p. 21.

2. HANGAN, A.C., STAN, R.L., TURZA, A., OPREAN, L.S., PALL, E., GHEORGHE-CETEAN, SINZIANA, SEVASTRE, B., Transit. Met. Chem., 42, no. 2, 2017, p. 153.

3. HANGAN, A.C., TURZA, A., STAN, R.L., SEVASTRE, B., PALL, E., CETEAN, S., OPREAN, L.S., J. Chem. Sci., 128, no. 5, 2016, p. 815. 
4. NICULESCU, V., MURESAN, N., SALAGEANU, A., TUCUREANU, C., MARINESCU, G., CHIRIGIU, L., LEPADATU, C., J ournal of Organometallic Chemistry, 700, 2012, p. 13.

5. TAMAIAN, R., PAUN, N., NICULESCU, V., IORDACHE, A., VREMERA, R., BROSCATEAN, S., Chemicke Listy, 102, 2008, s479.

6. RUSU, D., STANILA, A., MARIAN, I.O., MARIAN, C.O., RUSU, M., LUCACIU, R., Rev. Chim.(Bucharest), 60, no. 9, 2009, p. 939.

7. KIM, M.H., SEO, J.Y., LIU, K.H., KIM, J.S., PLOS ONE, 9, no.7, 2014, e101486.

8. SINGH, N.P., FERREIRA, J.F.S., PARK, J.S., LAI, H.C., Planta Med, 77, 2011, p. 1788.

9. de RIDDER, S., van der KOOY, F., VERPOORTE, R., J Ethnopharmacol, 120, 2008, p. 302.

10. NAILI, M.B., ALGHAZEER, R.O., SALEH., N.A., AL-NAJAR, A., Arab J Chem, 3, 2010, p. 79.

11. RUSTAYAN, A., MASOUDI, S., Phytochem Lett, 4, 2011, p. 440.

12. FERREIRA, J.F., LUTHRIA, D.L., SASAKI, T, HEYERICK, A., Molecules, 15, 2010, p. 3135.

13. SONG, Y., DESTA, K.T., KIM, G.S., LEE, S.J., LEE, W.S., KIM, Y.H., JIN, J.S., EL-ATY, A.M., SHIN, H.C., SHIM, J.H., SHIN, S.C., Biomed Chrom, 30, no. 4, 2016, p. 588.

14. CARBONARA, T., PASCALE, R., ARGENTIERI, M.P., PAPADIA, P., FANIZZI, F.P., VILLANOVA, L., AVATO, P., J Pharm Biomed Anal, 62, 2012, p. 79.

15. IQBAL, S., YOUNAS, U., CHAN, K.W., ZIA-UL-HAQ, M., ISMAIL, M., Molecules, 17, 2012, p. 6020.

16. LEE, J.H., LEE, J.M., LEE, S.H., KIM, Y.G., LEE, S., KIM, S.M., CHA, S.W., Hortic Environ Biotechnol, 56, no. 5, 2015, p. 697.

17. HANGAN, A.C., TURZA, A., STAN, R.L., 'TEFAN, R, OPREAN, L.S., Russ. J. Coord. Chem., 41, no. 6, 2015, p. 365.

18. HANGAN, A.C., STAN, R.L., SEVASTRE, B., GHEORGHE-CETEAN, S., OPREAN, Farmacia, 65, no. 3, 2017, p. 368.

19. HUANG, D., OU, B., PRIOR, R.L., J Agric Food Chem, 53, 2005, p. 1841.

20. JURCA, T., MARIAN, E., VICAS, L., GATEA, D., Rev Chim. (Bucharest), 62, no. 12, 2011, p. 1154.

21. VLASE, L., MOCAN, A., HANGANU, D., BENEDEC, D., GHELDIU, A., CRI'AN, G., Dig J Nanomater Bios, 9, no. 3, 2014, p. 1085.

22. BENEDEC, D., FILIP, L., VLASE, L., BELE, C., SEVASTRE, B., RAITA, O., OLAH, N.K., HANGANU, D., Pak J Pharm Sci, 29, no. 4, 2016, p. 1359.
23. ARSENE, A.L., RODINO, S., BUTU, A., PETRACHE, P., IORDACHE, 0., BUTU, M., Farmacia, 63, no. 6, 2015, p. 851.

24. BENEDEC, D., HANGANU, D., ONIGA, I., TIPERCIUC, B., OLAH, N.K., RAITA, O., BISCHIN, C., SILAGHI-DUMITRESCU, R., VLASE, L., Pak J Pharm Sci, 28, no. 6, 2015, p. 2297.

25. OLAH, N.K, OSSER, G., CAMPEAN, R.F., FURTUNA, F.R., BENEDEC, D., FILIP, L., RAITA, O., HANGANU, D., PakJ Pharm Sci, 29, No. 6, 2016, p. 2355.

26.HANGAN, A., BODOKI, A., OPREAN, L., CRI'AN, O., MIHALCA, I., Farmacia, 60, no.6, 2012.

27. HANGAN, A., BORODI, G., FILIP, X., TRIPON, C., MORARI, C., OPREAN, L., FILIP, C., Acta Cryst, B66, 2010, p. 615.

28. STAN, R.L., HANGAN, A.C., DICAN, L., SEVASTRE, B., HANGANU, D., CATOI, C., SARPATAKI, O., IONESCU, C.M., Acta Biologica Hungarica, 64, no. 3, 2013, p. 279.

29. SEVASTRE, B., SARPATAKI, O., STAN, R.L., TAULESCU, M., SEVASTREBERGHIAN, A.C., OLAH, N.K., FURTUNA, F., HANGANU, D., HANGAN, A.C., CENARIU, M., BÂLDEA, I., Farmacia, 65, no. 1, 2017, p. 56.

30. Farmacopeea Romana, Ediia X, Ed. Medicala, Bucuresti, 2008. 31. KIKUZAKI, H., HISAMOTO, M., HIROSE, K., AKIYAMA, K., TANIGUCHI, H., Journal Agriculture and Food Chemistry, 50, 2002, p. 2161.

32. ARNAO, M.B., CANP, A., ALCOLEA, J.F., ACOSTA, M., Phytochem Anal, 12, 2011, p. 138.

33.MARIAN, E., VICAS, L.G, JURCA, T., MURESAN, M., PALLAG, A., STAN, R.L., SEVASTRE, B., DIACONEASA, Z., IONESCU, C., HANGAN, A.C., Rev Chim. (Bucharest), 69, no. 2, 2018, p. 365.

34. JURCA, T., VICAS, L., TOTH, I., BRAUN, M., MARIAN, E., TEUSDEA, A., VICAS, S., MURESAN, M., Farmacia, 64, no. 4, 2016, p. 581.

35. PALLAG, A., PA'CA, B., JURCA, T., SUCIU, R, NEMETH, S., VICAS, L., Farmacia, 64, no. 3, 2016, p. 372.

36. MARIAN, E., VICAS, G.L., JURCA, T., MURESAN, M., STAN, R.L., SEVASTRE, B., DIACONEASA, Z., IONESCU, C., HANGAN, A.C., Farmacia, 65, no. 6, 2017, p. 940.

37. SEVASTRE, B., SARPATAKI, O., OLAH, N.K., STAN, R.L., TAULESCU, M., MARCUS, I., CATOI, C., Farmacia, 62, no. 5, 2014, p. 907.

38. HRAPKIEWICZ, K., MEDINA, L., Clinical Laboratory Animal Medicine: An Introduction, Blackwell Publishing Professional, Ames, lowa 50014, USA, 2013.

$\overline{\text { Manuscript received: } 7.06 .2018}$ 